\title{
The history of the parathyroid glands
}

\author{
Ilias-Dimitrios Kafetzis, Antonis Diamantopoulos, Ioannis Christakis, \\ Basileios Leoutsakos
}

General Hospital of Athens "Polikliniki Athinon", Athens, Greece

\section{THE DISCOVERY OF THE PARATHYROID GLANDS AND THEIR FUNCTION}

Greep $^{1}$ in 1963 as well as Pang and Epple ${ }^{2}$ in 1980 advanced the view that the parathyroids originally appeared 100 million years ago, in the context of the evolutionary development of amphibians. This coincided with the transition of life from the calcium-rich marine environment to the terrestrial or the aquatic environments. However, other authors ${ }^{3}$ have suggested that this took place 360-286 million years ago, during the carboniferous age.

The clinical findings of diseased parathyroids were known many centuries before their discovery, when their study as regards physiology and pathophysiology ensued. In 1931, Denninger ${ }^{4}$ reported that in Illinois, North America, certain 'fossil skeletons' showed evidence of 'osteitis fibrosa cystica' (Von Reklinghausen disease). Cook et $\mathrm{al}^{5}$ argued that similar findings were also reported in ancient Egypt.

Key words: Hyperparathyroidism, Parathormone, Parathyroid glands, Parathyroidectomy, Tetany

Address for correspondence:

Dr. Antonis Diamantopoulos

Tel: +306985578711, E-mail: tonyd30@windowslive.com

Dr. Ioannis Christakis

3 North End Crescent Road, Flat 1, London, W148TG,

United Kingdom

Tel: $+306948378537,+447919355262$,

E-mail: ichristakis@yahoo.com

Received 27-05-10, Revised 09-09-10, Accepted 11-10-10
Nicholas Culpeper (1616-1654) ${ }^{6}$ in 1650 was the first to use the term 'larigismus strimulus'. According to Taylor, ${ }^{7}$ the French surgeon Courtial described in 1743 a patient with very soft bones, like skin. Clark $(1761-1815)^{8}$ was the first to describe "a peculiar type of convulsions in children" which we now know was actually tetany. Steinheim (1789-1866 $)^{9}$ in 1830 in Germany and Dance (1797-1838) ${ }^{10}$ in France one year later described tetany. Interestingly, Dance considered that it was a disease peculiar to France, one which had "une paternité toute française". In 1852 Corvisard ${ }^{11}$ introduced for the first time the term 'tetanie' to cover all the abovementioned cases. The homonymous clinical signs of tetany were described by Trousseau (1801-1865) 12 in 1862, by Erbe (1890$1921)^{13}$ and finally by Ghvostek (1835-1884) $)^{14}$ in 1876 .

The existence of the parathyroid glands in humans was first noted in 1855 by Remark (1815-1865) ${ }^{15}$ and in 1863 by Virchow (1821-1922). ${ }^{16}$ The first who correlated parathyroid activity with diseases of the bone was Schlagenhaufer, ${ }^{17}$ a Viennese physician in 1915 reasoned that in patients with osteitis fibrosa cystica only one parathyroid gland was enlarged, suggesting that the bone disease was the result rather than the cause of parathyroid hyperplasia and that parathyroidectomy may alleviate the bone disease of these patients. This concept was tested in 1925 when the Viennese surgeon Felix Mandl ${ }^{18}$ removed a parathyroid adenoma from a patient with osteitis fibrosa cystica, resulting in dramatic relief of the bone disease. Unfortunately, the disease recurred seven years later and, despite repeated surgery, Mandl's patient died from this disease. 
However, Sir Richard Owen (1804-1892), ${ }^{19}$ Professor and Conservator of the Museum at the Royal College of Surgeons (RCS) of England, was the first to describe the parathyroid glands in 1852 . Richard Owen, on necropsy of a Great Indian Rhinoceros (Rhinoceros unicornis), described in detail a small, yellow, compact glandular body which was attached to the thyroid gland, where the veins emerged. $\mathrm{He}$ published his work as the third article in the fourth volume of the Society's Transactions, not in 1862 as commonly believed, but ten years earlier, in March 1852. It was Cave, successor to Owen as Professor of Anatomy at the RCS, who noted that Owen's paper had been published in 1852 and not in 1862 as originally thought. To honor Owen's achievement, Cave $^{20}$ in 1953 conferred on these glands the term "glands of Owen".

Although Owen's description is the earliest reference to the existence of the parathyroid glands, it is the Swedish-born Sandström (1852-1889) who is credited with discovering and naming the glands. ${ }^{21}$ In 1880 he came across structures in a dog's neck that were of interest to him. Having then identified the organ in other animals including cat, rabbit, ox and horse, Sandström proceeded to human anatomy and, to his astonishment, in the first individual examined "found on both sides of the inferior border of the thyroid an organ the size of a small pea". He named the new structures 'glandulae parathyroidae'. Sandström was not aware of Owen's description and, because his report was rejected by German editors, it was published in 1880 in a local Swedish journal, the 'Ups\&r Liikarefiirenings Fiirhundlinger', and went barely noticed for several years.

In the same year (1880), Anton Wülfler (18501917), Virchow's assistant and later professor of surgery in Graz and Prague, noticed some "tissues" with colloid in the thyroid gland, which most probably were intrathyroidal parathyroid glands, and he named them "foetal rests". Davis Colley in 1884 presented to the Pathological Society of London the clinical history and autopsy findings of a 13-year old girl who had died of a combination of skeletal and urinary tract disease. Histological findings in some of the osseous lesions were very suggestive of hyperparathyroidism, though ascribed by the author to osteomalacia.
The findings of Owen, Sandström and other researchers were not taken seriously until Gley (18571930), ${ }^{22}$ a French physiologist, rediscovered in rabbits in 1891 the lower parathyroids and began to investigate their physiology and pathology. He observed that the tetany and death caused by experimental thyroidectomy in dogs occurred only if the excised material included the glands described by Sandström and that these glands were essential for the maintenance of life. Gley in his report referred to the Sandström description of the parathyroids.

The first observations made about the substance (hormone) which is secreted by these glands is probably that of Moussu ${ }^{23}$ in 1898, who successfully but temporarily treated tetany in dogs, resulting from parathyroidectomy, by subcutaneous and intravenous injections of water or glycerine extracts of horse parathyroids.

In 1909 MacCallum and Voeghin (1879-1960) ${ }^{24}$ proposed that the main effect of the parathyroid hormone was on the calcium level in the plasma, since the removal of these glands resulted in calcium loss in excreta, further resulting in a drop of blood calcium levels and in the development of tetany.

During the same year (1909), Berkeley and Beebe ${ }^{25}$ were the first to show that the extract of these glands could relieve hypocalcemia and the resulting tetany in humans. They prepared an extract from bovine parathyroids from which they separated a nucleoprotein which appeared to them to have curative properties when administered to parathyroidectomized animals.

A considerable contribution to the knowledge regarding the treatment of hypoparathyroidism in humans was provided by Collip (1892-1965) ${ }^{26}$ who in 1925 asserted that: "The extraction of the parathyroid hormone (parathormone) prevents or controls parathyroid tetany and regulates the level of blood calcium". Furthermore, Rasmussen and Gravy ${ }^{27}$ in 1959 succeeded in purifying and isolating the parathormone. The purity of the substance was sufficiently high and could be prepared for definite chemical characterization as well as structural analysis. This research confirmed that parathormone is a complex polypeptide hormone.

However, inevitably errors were at times made by 
scientists working in this challenging field. In 1962 Copp et $\mathrm{al}^{28}$ reported the discovery of what he called "the new parathyroid hormone", which was observed to lower blood calcium. This hormone was named 'calcitonin'. Copp at that time wrongly assumed that calcitonin was a hypocalcemic factor which prevented the hypercalcemia that otherwise would result from excess parathormone production.

The notion of hyperparathyroidism and its detrimental effects on the human organism attracted the attention of scientists as early as 1864. It was Engel ${ }^{29}$ during that year who originally presented a patient with a parathyroid adenoma and skeletal disease. A similar condition was reported in 1904 by Askanazy $(1865-1940):{ }^{30}$ he was the first to connect 'osteitis fibrosa cystica' with humours of the parathyroids. A detailed description of this condition was provided in 1891 by von Recklinghausen. ${ }^{31}$

Albright (1900-1969) and Bloomberg et $\mathrm{al}^{32}$ suggested that primary hyperparathyroidism was due to a single adenoma of one gland or multiple adenomas with primary water-clear cell hyperplasia as well as to parathyroid carcinoma; they also described diffuse cell hyperplasia of all parathyroid glands. Albright and Reifenstein ${ }^{33}$ defined primary hyperparathyroidism in their book "The Parathyroid Glands and Metabolic Bone Disease", which was published in 1948 as: "Primary hyperparathyroidism is a condition in which the parathyroid hormone is higher than is needed". The secondary type is a condition where more parathyroid hormone is manufactured for some compensatory purposes. Later, the term 'tertiary hyperparathyroidism' was adopted for patients who have developed parathyroid tumours secondary to renal failure or intestinal malabsorption syndrome with osteomalacia.

Many surgeons who have left their mark on the development of surgery as a science have been intrigued by the parathyroid glands. The first transplantation of the parathyroids was performed by Schift and Horsley in 1885 as reported by Niederle, Roka et al, ${ }^{34}$ and von Eiselsberg. ${ }^{35}$ In 1892 von Eiselsberg ${ }^{35}$ performed a large number of auto-transplantations of the parathyroid glands in the peritoneum and the posterior wall of the sheath of the rectum abdominal muscle of cats. He thereby showed that tetany was absent and new vessels had formed in the transplants. Furthermore, tetany occurred after these transplants were removed.

Halstead $^{36}$ in Baltimore attempted "iso-autotransplantation of the parathyroid glands" in dogs in 1909. He transplanted the tissues of the glands under the abdominal skin or into the parenchyma of the thyroid gland. Halstead and several other researchers called this situation 'loan of insufficiency'. Later on, in 1936 Shambangh $^{37}$ pointed out that the abovementioned 'loan' was not necessary for successful transplantation of these glands. Since then, parathyroid glands transplantation, using of a range of different techniques, has been a common procedure for the treatment of hypoparathyroidism.

The first unsuccessful operation to treat skeletal disease was performed by Oscar Hirsch in Vienna in April 1925. He tried surgically to locate and remove a tumour of the parathyroid but did not succeed. During the same period, in Vienna the famous pathologist Erdheim $^{38}$ expressed his view that, since the tumours of the parathyroids are compensatory due to bone disease, the operation is contra-indicated.

It seems appropriate at this point to mention Captain Charles Martell who is certainly the most famous example of a patient with hyperparathyroidism: his case was described by Fuller Albright in a speech delivered while President of the American Society for Endocrinology. At the Massachusetts General Hospital in Boston, Martell was operated on twice in 1926, but without success. In 1932 Churchill $^{39}$ and Cope, performing their fifth operation on this patient managed to remove a parathyroid tumour measuring $3 \mathrm{~cm}$ in diameter from the mediastinum, after having to split the sternum. Unfortunately, the patient died within a month of the operation due to renal complications from his longstanding battle with the disease. Since then, many thousands of parathyroidectomies have been performed worldwide employing different surgical techniques. As from 1990 more and more conservative operations have been applied to treat primary hyperparathyroidism with very satisfactory results.

The discovery of the parathyroid glands and their function was without doubt a major breakthrough for the medical community. Given the tiny size of 
these glands (the size of a grain of rice), it is obvious that the early pioneers in the field of Endocrinology were hard put to accurately assess their nevertheless great importance. However, thanks to scientists like R. Owen, V. Sandström and E. Gley and to surgeons such as W.S. Halstead, Billroth and many others, huge progress has been made over the centuries which, combined with technological advances and human ingenuity, has significantly added, and continues to do so, to the total arsenal of medical knowledge regarding the parathyroids.

The authors report no grants or fellowship supports and no conflicts of interest.

\section{REFERENCES}

1. Greep RO, 1963 Parathyroid hormone. In Comparative Endocrinology. Ed. Von EULER, V.S. Heller H. New York Academic Press; pp, 325-370.

2. Pank RKT, Epple A, 1980 Evolution of the vertebrate endocrine systems. Graduate Studies Lubbock, Texas, Texas Tech University.

3. Leoutsakos B, 2006 The endocrinology in its historical course. 7. Parathyroids, John Parisianos (ed), Athens, Greece; pp, 337.

4. Denninger HS, 1931 Osteitis fibrosa in a skeleton of a prehistoric American Indian. Arch Path 11: 939-947.

5. Cook M, Molto E, Anderson C, 1988, Possible case of hyperparathyroidism in a Roman period skeleton from Dakhleh Oasis, Egypt, diagnosed using bone histomorphometry. Am J Phys Anthropol 75: 7523-7530.

6. Glisson F, 1650 A treatise of the rickets: being a disease common to children. Translated and edited by N. Culpeper. London, pp, 57-59.

7. Taylor S, 1986 History of hyperparathyroidism. In Foetmen (ed), Progress in Surgery. Parathyroid Surgery, New York; Karger 1-12.

8. Clarke J, 1815 Commentaries on some of the most important children's diseases Part 1 London Longman; pp, 86-97.

9. Steinheim SJ, 1830 Zwei seltene Formen von hitzigem Rheumatismus, Hecker's Annalen, Berlin, Enslin; pp, 22-30.

10. Dance BH, 1831 Observations sur une espèce de tétanus intermittent. Arch Gen Med 26: 190-205.

11. Corvisard FR 1852 De la contracture des extrémités en tétanie. These No 223, Paris.

12. Trousseau AR, 1861 Clinique medicale de l'Hôtel-Dieu de Paris, J.B. Bailliere (ed), Paris, France; pp, 112-114.

13. Erb WH, 1873 Zur Lehre von de Tetanie nebst Benerkungen über die Prüfung der elektrischen Erregbarkeit motoricher Nerven Arch. Psychiatr: Nervenkr 4: 271-316.

14. Chovstek F, 1876 Beitrag zur Tetanie Med. Presse (ed),
Wien; pp, 17, 1201-1203, 1225-1227, 1253-1258, 13141316.

15. Remak R, 1895 Untersuchungen über die Entwicklung der Wirbeltiere Greimer (ed), Berlin; pp, 194: 39-40, 122-124.

16. Wirchow R, 1863 Die krankhaften Geschwulste A. Hirschwall (ed), Berlin, pp; 3:13.

17. Schlagenhaufer F. Virchow's Arch. f. Path Anat, Berlin, 1907, CLXXXVII, 125.

18. Mandl F, 1926 Therapeutischer Versuch bei einem Falle von Ostitis Fibrosa Generalisata mittels Extirpation eines Epithelkorperchentumors. Zentralbl Chir, LIII: 260.

19. Owen R, 1862 On the anatomy of the Indian rhinoceros. Trans Zool Soc Lond 4:31-58.

20. Cave AJE, 1953 Science Medicine and History Essays written in honour of Charles Singer Underwood (Ed), Oxford University Press, London; Vol 2. pp; 217-222.

21. Sandstorm IV, 1880 Omen ny Kortel hos mennisken och atskilige baggdjur Lakarefore rings (ed), Upsala, pp; 441-471.

22. Gley E, 1891 Sur les fonctions du corps thyroïde. C Soc Biol 43: 841-847.

23. Meussu G, 1898 Sur la function parathyroïdienne. C R Biol 50: 876-869.

24. MacCallum G, Voeghin C, 1909 On the relation of tetany to the parathyroid glands and to the calcium metabolism. J Exp Med 11: 118-151.

25. Berkeley YWN, Beebe SB, 1909 A contribution to the physiology and chemistry of the parathyroid glands. J Med Re 20: 149-157.

26. Collip JB, 1925 The extraction of a parathyroid hormone which will prevent or control parathyroid tetany and which regulates the level of blood calcium. J Biol Chem 63: 395-438.

27. Rasmussen H, Craig L, 1959 Purification of parathormone by use of countercurrent distribution. J Amer Chem Soc 81: 5003.

28. Copp DH, Cameron EC, Cheney BA, Davidson AGF, Henze KG, 1962 Evidence for calcitonin - A new hormone from the parathyroid that lowers blood calcium. Endocrinology 70: 638-649.

29. Engel G, 1864 Über einen Fall von cystoider Entartung des ganzen Skelletes Giessen F.C., Pietsch.

30. Askanazy M, 1904 Über Ostitis deformans ohne osteoides Gewebe Arb. Path Anat Inst Tübingen 4: 398-422.

31. Von Recklinghausen FB, 1891 Die fibroese oder deforminzende Ostitis die Osteomalakie und die Osteoplastis de Carcinose in ihren regenseitigen Beziehungen In festehrift R. Virchow, Berlin.

32. Albright F, Bloomberg E, Castleman B, Churchill E, 1934 Hyperparathyroidism due to diffuse hyperplasia of all parathyroid glands rather than adenoma of one. Arch Inter Med 54: 315-329.

33. Albright F, Reifenstein FC, 1948 The parathyroid glands and metabolic bone disease.

34. Niederle B, Roka R, Brennan MF, 1892 The transplan- 
tation of parathyroid tissue in man. Endocrin Rev 3: 245-279.

35. Von Eiselberg A, 1892 Über erfolgreiche Einheilung der Katzen Schildrüse in die Baueehdecke und Auftreten von Tetanie nach der Extirpation.

36. Halstead WS, 1909 Auto and isotransplantation in dogs of the parathyroid glands. J Exp Med 11: 175-199.
37. Shambaugh R, 1936 Autotransplantation of parathyroid glands. Arch Surg 32: 709-715.

38. Erdheim J, 1906 Über Epithelköperehenbelung bei Osteomalakie S.B. Arad Wiess Math Nature G 1: 116-311.

39. Churchill EB, 1934 The operative treatment of hyperparathyroidism. Ann Surg 100: 606-612. 